\title{
STABLE ISOTOPES IN ENVIRONMENTAL INVESTIGATIONS
}

\author{
A. Mašalaitè, A. Garbaras, and V. Remeikis \\ Center for Physical Sciences and Technology, Savanoriu 231, LT-02300 Vilnius, Lithuania \\ E-mail: agne.masalaite@ftmc.lt
}

Received 10 August 2012; revised 21 September 2012; accepted 21 September 2012

\begin{abstract}
This paper presents an overview of the most common stable isotopes $(\mathrm{H}, \mathrm{C}, \mathrm{N}, \mathrm{O}$, and $\mathrm{S})$ that are widely used in environmental research. Much attention is given to the atmospheric aerosol particle studies involving stable isotopes. Finally, the experimental results of the carbon stable isotope composition $\left(\delta^{13} \mathrm{C}\right)$ in fuels from various locations (Eastern and Western Europe, China, Japan) are discussed. Additionally, recommendations for future research directions are proposed.
\end{abstract}

Keywords: aerosols in atmosphere, stable isotopes, $\delta^{13} \mathrm{C}$, fuel

PACS: 92.60.Mt, 32.10.Bi, 88.20.th

\section{Introduction}

Isotopic analysis has become almost a standard tool for all scientists studying element or material cycling in the environment. The article focuses on two problems. The first one is to introduce a stable isotope mass spectroscopy method which helps using carbon, nitrogen, oxygen, and hydrogen stable isotope ratios as markers in solving problems of environmental investigation. The second problem is a way to deal with the evaluation of aerosol sources by using the isotopic composition of fuel. The major part of the text particularly deals with the description of a wide range of environmental investigations made using stable isotopes. A brief discussion on the measured isotopic composition of fuel is given in the end. It is a major priority, because atmospheric aerosols exert a highly uncertain effect on radiative climate forcing, have an important influence on visibility and serious impacts on human health. However, there are significant uncertainties about the true impact of atmospheric aerosols on climate and health because of a lack of knowledge of their sources, composition, properties, and mechanisms of formation.

\section{Application of stable isotopes}

Most elements of environmental interest have two or more stable isotopes, with the lightest of these present in much greater abundance than the others [1]. The main concern in this article is given to the hydrogen $(\mathrm{H})$, carbon $(\mathrm{C})$, nitrogen $(\mathrm{N})$, oxygen $(\mathrm{O})$, and sulphur $(\mathrm{S})$ stable isotopes. These elements are found in the Earth's terrestrial ecosystems, the atmosphere, and all living things. Average terrestrial abundances of the stable isotopes of some elements are given in Table 1 .

Most studies express the isotopic composition in terms of $\delta$ values which are parts per thousand differences from a standard [2]:

Table 1. Average terrestrial abundances of the stable isotopes of major elements of interest in environmental studies [1].

\begin{tabular}{c|c|c}
\hline Element & Isotope & Abundance, $\%$ \\
\hline Hydrogen & ${ }^{1} \mathrm{H}$ & 99.985 \\
\hline & ${ }^{2} \mathrm{H}$ & 0.015 \\
\hline Carbon & ${ }^{12} \mathrm{C}$ & 98.89 \\
\hline & ${ }^{13} \mathrm{C}$ & 1.11 \\
\hline Nitrogen & ${ }^{14} \mathrm{~N}$ & 99.63 \\
\hline & ${ }^{15} \mathrm{~N}$ & 0.37 \\
\hline Oxygen & ${ }^{16} \mathrm{O}$ & 99.759 \\
\hline & ${ }^{17} \mathrm{O}$ & 0.037 \\
\hline Sulphur & ${ }^{18} \mathrm{O}$ & 0.204 \\
\hline & ${ }^{32} \mathrm{~S}$ & 95.02 \\
\hline & ${ }^{33} \mathrm{~S}$ & 0.75 \\
\hline & ${ }^{34} \mathrm{~S}$ & 4.21 \\
\hline & ${ }^{36} \mathrm{~S}$ & 0.02 \\
\hline
\end{tabular}




$$
\delta^{\mathrm{H}} X=\left[\left(R_{\text {sample }} / R_{\text {standard }}\right)-1\right] \times 1000,
$$

where ${ }^{\mathrm{H}} \mathrm{X}$ is ${ }^{2} \mathrm{H},{ }^{13} \mathrm{C},{ }^{15} \mathrm{~N},{ }^{18} \mathrm{O}$, or ${ }^{34} \mathrm{~S}$. The $\delta$ values are measures of the amounts of heavy and light isotopes in a sample. Positive $\delta$ values reflect enrichment in heavy isotopes, and negative $\delta$ values indicate relatively lighter isotopes than those present in the sample [1].

Stable carbon isotopes $\left({ }^{13} \mathrm{C}\right.$ and $\left.{ }^{12} \mathrm{C}\right)$ have been proved to be useful geochemical markers, and these isotopes were first applied to the studies of air pollution in the 1980s [3]. In the studies [4, 5] carbon isotopes and the ratio of elemental carbon (EC) to total carbon (TC) in aerosol particles were used to investigate emissions from biomass burning.

The data on the stable carbon isotope ratio $\left(\delta^{13} \mathrm{C}\right)$ can provide important information regarding the sources and the processing of atmospheric organic carbon species [6]. The carbon cycle involves active exchanges of $\mathrm{CO}_{2}$ among the atmosphere, terrestrial ecosystems, and the surface of the ocean. The $\delta^{13} \mathrm{C}$ value of atmospheric $\mathrm{CO}_{2}$ is decreasing in response to the inputs of ${ }^{13} \mathrm{C}$ depleted $\mathrm{CO}_{2}$ from fossil fuel plus biomass burning and decomposition. Over the past 100 years the decrease might have been almost $1 \%$, from about $-7 \%$ o to $-8 \%$ [ [2].

In the study [ [] a combination of ground-based and satellite observations was used to investigate different sources of aerosol loadings over Lithuania during two different time periods. The negative carbon isotopic mean value $(-30.9 \pm 0.2 \%)$ during 31 March-2 April 2008 obviously indicates that a major part of carbon mass in aerosol particles transferred by the continental air masses is from wildfire location.

In the study [8] a Cambrian crude oil from the central Tarim basin, along with its main separated fractions, was pyrolysed in sealed gold tubes to investigate how generated gases vary in the chemical and carbon isotopic composition and how this variation would influence the genetic interpretation of oil cracking gas.

The stable carbon isotope ratios obtained from tree rings are used to reconstruct climate parameters, such as temperature, humidity [9, 10], and to find a response of trees to changes in atmospheric chemistry [11].

The interest in atmospheric aerosols that have carbon in their composition is increasing; however, studies on using stable carbon isotopes in charac- terising air pollution are scarce [12]. In study [13] the bulk carbon isotopic composition of organic matter in aerosols to assess sugar cane sources was determined. In another study [14] a wet oxidation method for the measurement of compound specific $\delta^{13} \mathrm{C}$ of organic acids in the atmosphere was presented. Furthermore, stable carbon isotope ratios have been used to characterise the ageing of air masses [12, 15]. It is very relevant to experimentally confirm the statements that properties and behaviour of atmospheric aerosols that have carbon in their composition in the processes occurring in the atmosphere are determined by organic compounds formed during biomass and fossil fuel burning or by natural compounds formed in forests, on the sea surface, etc. The isotopic composition of $\mathrm{CO}_{2}$ provides a tracer that can be used to identify sources and sinks of $\mathrm{C}$ on the local, regional, and global scale if the anthropogenic fossil fuel signals are known.

Most nitrogen is present in the biosphere as $\mathrm{N}_{2}$ gas in the atmosphere. This massive reservoir is well mixed with an isotope composition that is essentially constant at $0 \%$ [2]. Aerosol particles, as condensation nuclei, are crucial to cloud formation in the atmosphere because of the temperatures and relative humidities at which clouds are observed to exist [16]. It is very important to determine the stable nitrogen isotope ratio for the nitrogenous substances in aerosols and the geochemistry behaviour of stable nitrate ion isotopes in aerosols in order to elucidate the chemical and physical functions of clouds [17].

A detailed research was made in the study [18] where the sources and chemistry of organic nitrogen aerosols in the atmosphere were explored.

There is a wide range of data reported for nitrogen isotope values from about $-20 \%$ o to $10 \%$ ofor ammonium and nitrate in precipitation [1, 2]. It is a very useful method to use $\delta^{15} \mathrm{~N}$ measurements to trace anthropogenic pollutant plumes and identify the sources and fates of $\mathrm{N}$ that human activities are adding to forests and lakes. Moreover, during combustion in an engine, oxygen atoms dissociate at high temperatures and start the chain reaction which is the oxidation of nitrogen to $\mathrm{NO}$ and $\mathrm{NO}_{2}$.

Isotopic analysis of carbon and nitrogen is very common in ecological research [19] while coupled with palynological analysis it is applied in identifying the possible origin of PM10-sized particles as well as in providing additional information about the air quality influencing human health [20]. 
There are three oxygen isotopes that act as tracers when many common oxygen-containing molecules circulate in the biosphere, namely ${ }^{16} \mathrm{O},{ }^{17} \mathrm{O}$, ${ }^{18} \mathrm{O}$. The isotopes of oxygen are increasingly used to track the global balance [2]. Hydrothermal activity is one of the most important processes acting on the Earth's crust, because it is ubiquitous and significant to geothermal energy and ore deposition. ${ }^{18} \mathrm{O} /{ }^{16} \mathrm{O}$ data provide evidence on a vigorous, shortlived ( $\approx 10$ years), high-temperature, fumarolic meteoric-hydrothermal event [21].

Stable oxygen isotopes are a good way to track the global balance in evaporation and condensation of water along with $\mathrm{O}_{2}$ dynamics in a metabolic context.

The stable isotope composition of sulphur entering the atmosphere can be quite variable. The oxidation of $\mathrm{SO}_{2}$ to sulphate occurs with an overall inverse effect that favours concentration of the heavy ${ }^{34} \mathrm{~S}$ isotope in the product of sulphate; this inverse effect arises from an equilibrium step between $\mathrm{SO}_{2}$ and $\mathrm{HSO}_{3}{ }^{-}$prior to final oxidation to sulphate [1].

It is well-known that oceanic areas of high primary productivity emit dimethylsulphide (DMS) [22], which is converted into submicrometer-sized sulphate and methanesulphonate aerosols within the atmosphere, and that these aerosols can affect cloud albedo and climate [23].

The stable isotope composition of sulphur entering the atmosphere can be really variable. New studies using the $\delta^{34} S$ value may clarify the relative contributions of human versus natural sources of the sulphur compounds $\left(\mathrm{SO}_{2}, \mathrm{SO}_{4}{ }^{2-}\right.$, etc.).

Stable hydrogen isotope $(\delta \mathrm{D})$ measurements have been successfully used to quantify breeding origins of migratory songbirds and insects that migrate across naturally occurring hydrogen isotopic gradients in North America [24, 25]. The quantitative information gained in such isotope studies can be used to improve wildlife management decisions and has focused attention on detrimental effects of genomics on nontarget species [26]. The measurements of $\delta \mathrm{D}$ can also be used to evaluate the biological isotopic fractionation [27], decipher tropic relationships [28], and aid in paleoclimatic reconstructions using fossil materials [29, 30]. Despite new and increasing applications in environmental studies, determinations of the stable-hydrogen isotope composition of complex organic substrates are hampered by laborious preparation techniques and uncontrolled isotopic exchange between labile hydrogen in the sample and ambient water vapour.

During the past decade a new technique using Cr metal as the active reactor component for a rapid, on-line continuous-flow reduction of waters for the natural abundance stable isotopic measurement of hydrogen was developed and tested [31]. Nowadays global application of stable hydrogen is used in wildlife forensics [32].

Ocean water is the main reservoir of hydrogen in the biosphere and the standard reference material (SMOW) for hydrogen isotope measurements. The isotope composition of ocean water represents a good starting point for following the isotope dynamics in the hydrological cycle.

For the identification of the location and origin of a pollution source the investigations of relative variations of various other isotopes are also used. Recent studies suggest [33-36] that coal combustion has become an important source of $\mathrm{Pb}$ in aerosols in urban and remote areas. Accordingly, lead isotopic ratios are used for tracing the urban atmospheric aerosols [37].

\section{Stable isotopes in atmospheric aerosols}

Atmospheric aerosols consisting of liquid or solid particles suspended in air play an important role in many chemical processes occurring in the atmosphere. The chemical composition is a major factor that controls the atmospheric effects of aerosol particles [38]. Furthermore, the protuberant role of atmospheric aerosol particles in the radiative transfer within the atmosphere by scattering and absorbing electromagnetic radiation makes them an important parameter in modelling the Earth's climate.

Globally, aerosols interact both directly and indirectly with incoming solar radiation. The direct effect is when aerosols such as ammonium sulphate scatter sunlight directly back into space while other aerosols such as black carbon absorb radiation [6]. Meanwhile the indirect effect is when aerosols in the lower atmosphere can modulate cloud properties due to changes in the concentration of cloud condensation nuclei. This has a potential for altering cloud albedo and changing cloud lifetime.

However, there are significant uncertainties about the true impact of atmospheric aerosols on 
climate and health because of a lack of knowledge about their sources, composition, properties and mechanisms of formation [39-41].

The measurement of aerosols has been widely practiced for several decades. Until recently, the development of new measurement methods was primarily motivated by the need to evaluate particulate pollution control devices and to find out better means of monitoring indoor and outdoor aerosols. During the resent several years, industry has become increasingly interested in modern aerosol measurement methods not only to protect the health of their workers as required by law but also to increase productivity and thereby gain competitive advantage [42].

Particles produced by diesel and spark-ignition engines are of great concern to engine builders since they influence engine performance and wear and because of their impact on the environment. The main concerns about these particles are environmental, namely adverse health effects, decreased visibility, and soiling of buildings. Recently, much attention worldwide has been given to the influence of fine particles in the atmosphere on human health [43-45.

In the study [46] the dual carbon isotope analysis method to a subset of six clean marine and polluted aerosol samples demonstrating the ability to discern contribution of three principal sources to atmospheric aerosols, marine, continental nonfossil, and fossil fuel, was applied.

The application of mass spectrometric techniques to the real-time measurement and characterisation of aerosols represents a significant advance in the atmospheric science. The basic types of aerosol mass spectrometers have been recently summarised in a review by Nash et al. [47].

Stable isotope mass spectrometry is a useful technique for global climate change research [48] and for identification of atmospheric carbonaceous aerosol sources [49, 50]. Stable isotope ratio mass spectrometry and computer modelling can be very useful to restore the irradiation parameters of graphite or other carbonaceous materials by using experimental and modelling results of ${ }^{13} \mathrm{C}$ generation in the irradiated material [51]; consequently, by combining aerosol mass spectrometry, stable isotope mass spectrometry, chromatography, and computer modelling the solutions of environmental problems in the future can be found.

\section{Materials and methods}

Our investigation revealed a possibility of the stable carbon isotopic ratio method to identify atmospheric carbonaceous aerosol sources. Fuel samples were taken from various locations. Diesel samples were obtained from Byelorussia, China, the Czech Republic, France, Germany, Lithuania, Switzerland, and Ukraine, while gasoline samples were obtained from Japan and Lithuania. The E85 fuel (from Lithuania) consisted of $85 \%$ of ethanol and $15 \%$ of gasoline.

The fuel samples were analysed with the FlashEA 1112 elemental analyser connected to the ThermoFinnigan Delta Plus Advantage stable isotope ratio mass spectrometer. The samples were placed into a tin capsule and combusted in an oxidation furnace at the $1020{ }^{\circ} \mathrm{C}$ temperature with oxygen excess. The carbon of the sample was oxidised into $\mathrm{CO}_{2}$. Later this gas passed into a reduction furnace $\left(650^{\circ} \mathrm{C}\right)$. The water from the sample in the He flow was removed using a magnesium perchlorate trap. Then the gas mixture was separated in the PoraPlot Q column $\left(50{ }^{\circ} \mathrm{C}\right)$. Separated gas passed through the ConFlow III gas distribution device to a mass spectrometer ionization cell.

All stable carbon isotope data are reported in the delta notation $\left(\delta^{13} \mathrm{C}\right)$ relative to Pee Dee Belemnite (PDB). Analytical precision and calibration of reference gas $\mathrm{CO}_{2}$ to $\mathrm{PDB}$ were estimated by a repeated analysis of certified reference material BCR 657, which gave an average $\delta^{13} \mathrm{C}$ of $-10.76 \%$ and standard deviation equal to $0.08 \%$ (certified value is $-10.76 \pm 0.04 \%$ ) .

\section{Results}

Isotopic analysis of diesel fuel in Lithuania and other East European countries (Byelorussia, Ukraine, the Czech Republic) shows that the carbon isotopic values of this fuel are comparable (Table 2). That is not surprising knowing that crude oil for diesel production is of Russian origin. In general, an isotopic composition of fuel in the Baltics and in Eastern Europe differs from that in the countries using fuel of other than Russian origin.

As it is seen from Table 2 diesel fuel in Western Europe is more enriched in heavier carbon isotopes (has more positive values) compared to the fuel of Russian origin. Diesel fuel from China has 
Table 2. Our results: measured $\delta^{13} \mathrm{C}$ in diesel and gasoline.

\begin{tabular}{cc}
\hline Sample location and measurement year & $\delta^{13} \mathrm{C}, \% 0$ \\
\hline Diesel & \\
\hline Basel, Switzerland, 7\% bio, 2009 & $-26.9 \pm 0.1$ \\
\hline Battenheim Total Excell, France, 2009 & $-27.2 \pm 0.1$ \\
\hline Byelorussia, 2010 & $-30.9 \pm 0.1$ \\
\hline China, 2009 & $-27.2 \pm 0.1$ \\
\hline Ferney-Voltaire, France, 2009 & $-25.8 \pm 0.3$ \\
\hline Kiev, Ukraine, 2008 & $-31.1 \pm 0.4$ \\
\hline Lithuania, 2007 & $-30.6 \pm 1.1$ \\
\hline Lithuania, 2009 & $-31.4 \pm 0.5$ \\
\hline Lithuania, 2010 & $-31.6 \pm 0.1$ \\
\hline Lithuania, diesel for farmers, 2009 & $-31.6 \pm 0.1$ \\
\hline Maulbronn, Germany, 7\% bio, 2009 & $-27.0 \pm 0.3$ \\
\hline Prague, Czech Republic, 2009 & $-31.1 \pm 0.1$ \\
\hline Gasoline & $-30.1 \pm 0.3$ \\
\hline Lithuania, 2010 & $-28.6 \pm 0.7$ \\
\hline Lithuania, E85, 2010 & $-26.6 \pm 0.1$ \\
\hline Tokyo, Japan, 2010
\end{tabular}

$\delta^{13} \mathrm{C}$ values similar to these of the fuel from Western Europe. In Lithuania, the carbon isotope values of gasoline are similar to those of diesel fuel. The E85 fuel, which is composed of $15 \%$ of gasoline and $85 \%$ of ethanol, reflects the isotopic composition of ethanol used for fuel production. The gasoline from Japan has $\delta^{13} \mathrm{C}$ values which are the same as those of diesel fuel from China, implying the same source of crude oil for this region.

In the study by Bush et al. [52], $\delta^{13} \mathrm{C}$ of crude petroleum showed a fairly high degree of variability, with samples from a single refinery ranging from $-25.9 \%$ o to $-31.5 \%$ o (the mean of $-28.8 \pm 1.6 \%$ ), but were not as variable as known global variations. Globally, $\delta^{13} \mathrm{C}$ of crude petroleum varies from $-19 \%$ to $-35 \%$, depending on geographic origin [53, 54].

Meanwhile, the carbon isotopic composition of gasoline collected from various distributors in Mexico City (Mexico) varied from $-26.7 \pm 0.26 \%$ to $-28.8 \pm 0.07 \%$ and $\delta^{13} \mathrm{C}$ value of diesel was $-27.4 \pm 0.01 \%$ [ [55] (Table 3). A very similar value of diesel $(-27.9 \pm 0.5 \%)$ was adduced in the measurements performed in Paris (France) [56]. The carbon isotopic composition of anthropogenic $\mathrm{CO}_{2}$ measured in Wroclaw for two types of car fuel (gasoline and diesel) was introduced in the study [57]. The value of $\mathrm{CO}_{2}$ originating from the combustion of diesel was $-31.9 \pm 0.3 \%$ and of gasoline
$-31.7 \pm 0.3 \%$. These values are slightly different from those determined by Widory [56] (average value $-28.8 \pm 0.4 \%$ ), which was probably caused by a locally variable character of fuels used for car combustion. It is possible to calculate the carbon isotopic composition of fuel using the equation from the study [56]:

$$
\delta^{13} \mathrm{C}_{\mathrm{CO}_{2}}=0.99( \pm 0.01) \times \delta{ }^{13} \mathrm{C}_{\text {fuel }}-1.3( \pm 0.5) \% \text {, }
$$

Results show that the carbon isotopic composition of diesel was $-30.9 \pm 0.3 \%$ and of gasoline $-30.7 \pm 0.3 \%$ in Wroclaw [57]. These values are quite different from those offered by other authors [55, 56]. However, this fuel is more enriched in heavier carbon isotopes - the same as the fuel from Lithuania.

The carbon isotopic composition values of oil taken from various places are given for comparison in Table 3 [58]. $\delta^{13} \mathrm{C}$ varied from $-20.7 \%$ (Italian oil) to $-32.3 \%$ (North Sea oil). It shows that evaluations of aerosol sources by using the

Table 3. $\delta^{13} \mathrm{C}$ values of diesel, gasoline and exhaust $\mathrm{CO}_{2}$ from literature.

\begin{tabular}{cc}
\hline Sample location and measurement year & $\delta^{13} \mathrm{C}, \% \mathrm{o}$ \\
\hline Oil [58] & -20.7 \\
\hline Italian & -25.2 \\
\hline Guatemalan & -32.3 \\
\hline North Sea & -30.6 \\
\hline Zairian & -26.3 \\
\hline Angolan & $-27.4 \pm 0.01$ \\
\hline Diesel & $-27.9 \pm 0.5$ \\
\hline Mexico City, Mexico, 2000 [55] & $-30.9 \pm 0.3$ \\
\hline Paris, France, 2005 [56] & $-31.9 \pm 0.3$ \\
\hline Wroclaw, Poland, 2008 [57] & $-28.6 \pm 0.2$ \\
\hline $\mathrm{CO}_{2}$, Wroclaw, Poland, 2008 [57] \\
\hline Gasoline & $-27.3 \pm 0.1$ \\
\hline Mexico City, Mexico, (87octane), 2000 [55] & $-28.8 \pm 0.07$ \\
\hline Mexico City, Mexico, (93 octane), 2000 [55] & $-28.2 \pm 0.05$ \\
\hline $\begin{array}{c}\text { Salt Lake City, USA, 2002 } \\
\text { (Sinclair distributor) [52] }\end{array}$ & $-27.3 \pm 0.06$ \\
\hline $\begin{array}{c}\text { Salt Lake City, USA, 2002 } \\
\text { (Chevron distributor) [52] }\end{array}$ \\
\hline $\begin{array}{c}\text { Salt Lake City, USA, 2002 } \\
\text { (Tesoro distributor) [52] }\end{array}$ \\
\hline $\begin{array}{c}\text { Salt Lake City, USA, 2002 } \\
\text { (Phillips 66 distributor) [52] }\end{array}$ & $-26.7 \pm 0.26$ \\
\hline Wroclaw, Poland, 2008 [57] & $-30.7 \pm 0.3$ \\
\hline $\mathrm{CO}_{2}$, Wroclaw, Poland, 2008 [57] & $-31.7 \pm 0.3$ \\
\hline \begin{tabular}{c} 
CO ${ }_{2}$, Paris, France, 2005 [56] \\
\hline
\end{tabular} & $-28.8 \pm 0.4$ \\
\hline
\end{tabular}


isotopic composition of fuel are not significant globally but very important for pollution research locally.

\section{Conclusions}

A review of new articles shows that natural abundance isotope signatures can be used to find patterns and mechanisms at a single organism level as well as to follow the whole ecosystem. The possibility of solving many environmental problems by using stable isotopes in correct and creative ways is analysed in the paper. The stable isotopic ratio method combined with aerosol mass spectrometry, chromatography, and computer modelling is suitable for the identification of atmospheric aerosol sources and for a better understanding of many chemical processes occurring in the atmosphere in which aerosols play an important role.

The results presented are the first measured stable carbon isotopic data of car fuel in Lithuania. Our investigation focused on car fuel, as the private car is an important source of air pollution and an important consumer of energy. The measurement data of the stable carbon isotopic values of diesel fuel (average value $\delta^{13} \mathrm{C}=-31.3 \pm 0.1 \%$ ) show that the isotopic composition of fuel in Lithuania and in Eastern Europe differs from fuel in the countries which use fuel of other than Russian origin (average value $\delta^{13} \mathrm{C}=-26.8 \pm 0.1 \%$ ) and these data can be used to identify the source of the fuel.

A comparison of our data and the data from literature shows that evaluation of aerosol sources by using the isotopic composition of fuel is not significant globally but is a sensitive tracer in the field of identifying atmospheric pollution sources locally. Besides, it was confirmed that estimation of the impact of exhaust gases from the vehicles on aerosol particles can be done using the carbon isotope composition. We can conclude that further investigations into this issue are necessary.

\section{Acknowledgements}

Postdoctoral fellow A.Mašalaitè gratefully acknowledges the funding of this work by the European Union Structural Funds Project Postdoctoral Fellowship Implementation in Lithuania.

\section{References}

[1] W. Rundel, J.R. Ehleringer, and K.A. Nagy, Stable Isotopes in Ecological Research (Springer-Verlag, New York, 1989).

[2] B. Fry, Stable Isotope Ecology (Springer, USA, 2006).

[3] R. Chesselet, M. Fontugne, and P. Buat-Menard, The origin of particulate organic carbon in the marine atmosphere as indicated by its stable carbon isotopic composition, Geophys. Res. Lett. 8, 345-348 (1981).

[4] H. Cachier. P. Buat-Menard, M. Fontugne, and J. Rancher, Source terms and source strengths of the carbonaceous aerosol in the tropics, J. Atmos. Chem. 3, 469-489 (1985).

[5] H. Cachier, P. Buat-Menard, and M. Fontugne, Long-range transport of continentally-derived particulate carbon in the marine atmosphere: evidence from stable carbon isotopes studies, Tellus B 38, 161-177 (1986).

[6] R. Fisseha, M. Saurer, M. Jaggi, R.T.W. Siegwolf, J. Dommena, S. Szidat, V. Samburova, and U. Baltensperger, Determination of primary and secondary sources of organic acids and carbonaceous aerosols using stable carbon isotopes, Atmos. Environ. 43, 431-437 (2009).

[7] V. Ulevicius, S. Byčenkiené, V. Remeikis, A. Garbaras, S. Kecorius, J. Andriejauskiene, D. Jasinevičienè, and G. Mocnik, Characterization of pollution events in the East Baltic region affected by regional biomass fire emissions, Atmos. Res. 98, 190-200 (2010).

[8] T. Hui, X. Xianming, R. Wilkins, and T. Yonghun, An experimental comparison of gas generation from three oil fractions: Implications for the chemical and stable carbon isotopic signatures of oil cracking gas, Org. Geochem. 46, 96-112 (2012).

[9] G.H.F. Young, D. McCarroll, N.J. Loader, and A.J. Kirchhefer, A 500-year record of summer nearground solar radiation from tree-ring stable carbon isotopes, Holocene 20 (3), 315-324 (2010).

[10] N.J. Loader, I. Robertson, and D. McCarroll, Comparison of stable carbon isotope ratios in the whole wood, cellulose and lignin of oak tree-rings, Palaeogeogr. Palaeoclimatol. Palaeoecol. 196, 395407 (2003).

[11]D. McCarroll, M.H. Gagen, N.J. Loader, I. Robertson, K.J. Anchukaitis, S. Los, G.H.F. Young, R. Jalkanen, A. Kirchhefer, and J.S. Waterhouse, Correction of tree ring stablecarbonisotope chronologies for changes in the carbon dioxide content of the atmosphere, Geochim. Cosmochim. Act. 73, 1539-1547 (2009).

[12]J. Rudolph, Gas chromatography-isotope ratio mass spectrometry, in: Volatile Organic Compounds in the Atmosphere, ed. R. Koppmann (Blackwell Publisher, Oxford, 2007) pp. 388-466. 
[13] L.A. Martinelli, P.B. Camargo, L.B.L.S. Lara, R.L. Victoria, and P. Artaxo, Stable carbon and nitrogen isotopic composition of bulk aerosol particles in a C4 plant landscape of southeast Brazil. Atmos. Environ. 36, 2427-2432 (2002).

[14]R. Fisseha, M. Saurer, M. Jaggi, S. Szidat, R.T.W. Siegwolf, and U. Baltensperger, Determination of stable carbon isotopes of organic acids and carbonaceous aerosols in the atmosphere, Rapid Commun. Mass Spectrom. 20, 2343-2347 (2006).

[15] H. Wang and K. Kawamura, Stable carbon isotopic composition of low-molecular-weight dicarboxylic acids and ketoacids in remote marine aerosols, J. Geophys. Res. 111, D07304 (2006).

[16]H. Yu, P.K. Quinn, G. Feingold, R.A. Kahn, M. Chin, and S.E. Schwartz, Remote sensing and in situ measurements of aerosol properties, burdens, and radiative forcing, in: Atmospheric Aerosol Properties and Climate Impacts, A Report by U. S. Climate Change Science Program and the Subcommittee on Global Change Research (National Aeronautics and Space Administration, Washington, D.C., U.S.A, 2009) pp. 44-49.

[17]H. Katsura, The effect of electrically charged clouds on the stable nitrogen isotope ratio and the anion concentrations in cloud-based aerosols, Int. J. Environ. Res. 6(2), 457-466 (2012).

[18]M.E. Erupe, Sources and Source Processes of Organic Nitrogen Aerosols in the Atmosphere, All Graduate Theses and Dissertations (Utah State University, 2008), retrieved 23 July, http://digitalcommons.usu.edu/etd/196.

[19]G. Trakimas, T.D. Jardine, R. Barisevičiūtè, A. Garbaras, R. Skipitytè, and V. Remeikis, Ontogenetic dietary shifts in European common frog (Rana temporaria) revealed by stable isotopes, Hydrobiologia 675, 87-95 (2011).

[20]M. Górka, E. Zwolińska, M. Malkiewicz, D. Lewicka-Szczebak, and M.O. Jędrysek, Carbon and nitrogen isotope analyses coupled withpalynological data of PM10 in Wrocław city (SW Poland) - assessment of anthropogenic impact, Isot. Environ. Health Stud. 48, 327-344 (2012).

[21] E.W. Holt and Jr.H.P. Taylor, ${ }^{18} \mathrm{O} /{ }^{16} \mathrm{O}$ mapping and hydrogeology of a short-lived ( $\approx 10$ years) fumarolic $\left(>500^{\circ} \mathrm{C}\right)$ meteoric-hydrothermal event in the upper part of the $0.76 \mathrm{Ma}$ Bishop Tuff outflow sheet, California, J. Volc. Geoth. Res. 83, 115-139 (1998).

[22] A.J. Kettle and M.O. Andreae, Flux of dimethylsulfide from the oceans: A comparison of updated data sets and flux models, J. Geophys. Res. 105, 26793-26808 (2000).

[23] R.J. Charlson, J.E. Lovelock, M.O. Andreae, and S.G. Warren, Oceanic phytoplankton, atmospheric sulfur, cloud albedo and climate, Nature 326, 655661 (1987).
[24] L.I. Wassenaar and K.A. Hobson, Natal origins of migratory Monarch butterflies at wintering colonies in Mexico: New isotopic evidence, Proc. Natl. Acad. Sci. 95, 15436-15439 (1998).

[25] K.A. Hobson and L.I. Wassenaar, Linking breeding and wintering grounds of neotropical migrant songbirds using stable hydrogen isotopic analysis of feathers, Oecologia 109, 142-148 (1997).

[26] J.E. Losey, L.S. Rayor, and M.E. Carter, Transgenic pollen harms monarch larvae, Nature 399, 214 (1999).

[27]A. Schimmelmann and M.J. DeNiro, Stable isotopic studies on chitin III. The ${ }^{18} \mathrm{O} /{ }^{16} \mathrm{O}$ and $\mathrm{D} / \mathrm{H}$ ratios in arthropod chitin, Geochim. Cosmochim. Acta 50, 1485-1496 (1986).

[28] M.F. Estep and H. Dabrowski, Tracing food webs with stable hydrogen isotopes, Science 209, 15371538 (1980).

[29] A.B. Cormie, H.P. Schwarcz, and J. Gray, Relation between hydrogen isotopic ratios of bone collagen and rain, Geochim. Cosmochim. Acta 58, 377-391 (1994).

[30] R.F. Miller, P. Fritz, and A.V. Morgan, Climatic implications of $\mathrm{D} / \mathrm{H}$ ratios in beetle chitin, Palaeogeogr. Palaeoclimatol. Palaeoecol 66, 277288 (1988).

[31] J. Morrison, T. Brockwell, T. Merren, F. Fourel, and A.M. Philips, On-line high-precision stable hydrogen isotopic analyses on nanoliter water samples, Anal. Chem. 73, 3570-3575 (2001).

[32] G.J. Bowen, L.I. Wassenaar, and K.A. Hobson, Global application of stable hydrogen and oxygen isotopes to wildlife forensics, Oecologia 143, 337348 (2005).

[33] M.DiazSomoano, M. Kylander, D.J. Weiss, A. Lopez Anton, I. Suarez Ruiz, and R. Martınez Tarazona, in: International Conference on Coal Science and Technology (Nottingham, CD- paper 2P2, 2007).

[34]J. Chen, M. Tan, Y. Li, Y. Zhang, W. Lu, Y. Tong, G. Zhang, and Y.Li, A lead isotope record of Shanghai atmospheric lead emissions in total suspended particles during the period of phasing out of leaded gasoline, Atmos. Environ. 39, 1245-1253 (2005).

[35] W. Wang, X. Liu, L. Zhao, D. Guo, X. Tian, and F. Adams, Effectiveness of leaded petrol phase-out in Tanjin, China, based on the aerosol lead concentration and isotope abundance ratio, Sci. Total Environ. 364, 175-187 (2006).

[36] B.P. Jackson, P.V. Winger, and P.J. Lasier, Atmospheric lead deposition to Okefenokee Swamp, Georgia, USA, Environ. Pollut. 130, 445-451 (2004).

[37] D. Widory, S. Roy, Y. Moulec, G. Goupil, A. Cochere, and C. Guerrot, The origin of atmospheric particles in Paris: A view through carbon and lead isotopes, Atmos. Environ. 38, 953-961 (2004).

[38]J. Heintzenberg, Aerosols - physics and chemistry of aerosols, in: Encyclopaedia of Atmospheric 
Sciences, ed. J.R. Holton (Academic Press, Oxford, 2003) pp. 34-40.

[39] National Research Council (NRC), Research Priorities for Airborne Particulate Matter, IV Continuing Research Progress (National Academy Press, Washington, UDA, 2004).

[40]U. Poschl, Atmospheric aerosols: composition, transformation, climate and health effects, Angew. Chem. Int. Edit. 44, 7520-7540 (2005).

[41]Intergovernmental Panel on Climate Change (IPCC), Climate Change 2007: The Physical Science Basis (Cambridge University Press, UK, 2007).

[42] P. Kulkarni, P.A. Baron, and K. Willeke, Aerosol Measurement: Principles, Techniques, and Applications, 3rd ed. (John Wiley \& Sons, New Jersey, 2011).

[43] H. Wang and K. Kawamura, Stable carbon isotopic composition of low-molecular-weight dicarboxylic acids and ketoacids in remote marine aerosols, J. Geophys. Res. 111, D07304 (2006).

[44] A. Nel, Air pollution-related illness: effects of particles, Science 308, 804-806 (2005).

[45] D.B. Kittelson, Engines and nanoparticles: A review, J. Aerosol Sci. 29, 575-588 (1998).

[46] D. Ceburnis, A. Garbaras, S. Szidat, M. Rinaldi, S. Fahrni, N. Perron, L. Wacker, S. Leinert, V. Remeikis, M.C. Facchini, A.S.H. Prevot, S.G. Jennings, M. Ramonet, and C.D. O’Dowd, Quantification of the carbonaceous matter origin in submicron marine aerosol by ${ }^{13} \mathrm{C}$ and ${ }^{14} \mathrm{C}$ isotope analysis, Atmos. Chem. Phys. 11, 8593-8606 (2011).

[47] D.G. Nash, T. Baer, and M.V. Johnston, Aerosol mass spectrometry: An introductory review, Int. J. Mass Spectrom. 258, 2-12 (2006).

[48] P. Ghosh and W.A. Brand, Stable isotope ratio mass spectrometry in global climate change research, Int. J. Mass Spectr. 228, 1-33 (2003).

[49] A. Garbaras J. Andriejauskienè, R. Barisevičiūtè, and V. Remeikis, Tracing of Atmospheric aerosol sources using stable carbon isotopes, Lith. J. Phys. 48, 259-264 (2008).

\title{
STABILIEJI IZOTOPAI APLINKOS TYRIMUOSE
}

\author{
A. Mašalaitè, A. Garbaras, V. Remeikis
}

Valstybinis mokslinių tyrimų institutas Fizinių ir technologijos mokslų centras, Vilnius, Lietuva

\section{Santrauka}

Pateikta tyrimų ịvairiuose aplinkos sanduose, dažniausiai naudojant $\mathrm{H}, \mathrm{C}, \mathrm{N}$ ir $\mathrm{S}$ stabiliuosius izotopus, apžvalga. Plačiau aptariamos stabiliųjų izotopų taikymo galimybės atmosferos aerozolių tyrimuose, pvz., vertinant radiacinius ir cheminius procesus atmosferoje bei galimus klimato pokyčius, identifikuojant aerozolio dalelių šaltinius, nustatant aerozolio dalelių cheminę sudètị, vertinant lokalius taršos apkrovos dydžius bei ịtaką žmogaus sveikatai ir t. t. Galiausiai pateikiamos eksperimentiškai išmatuotos stabiliųjų anglies izotopų santykio
[50]A. Garbaras, I. Rimšelytè, K. Kvietkus, and V. Remeikis, $\delta^{13} \mathrm{C}$ values in size-segregated atmospheric carbonaceous aerosols at a rural site in Lithuania, Lith. J. Phys. 49, 229-236 (2009).

[51] V. Remeikis, A. Plukis, R. Plukiene, A. Garbaras, R. Barisevičiūtè, A. Gudelis, R. Gvozdaitè, G. Duškesas, and L. Juodis, Method based on isotope ratio mass spectrometry for evaluation of carbon activation in the reactor graphite, Nucl. Eng. Des. 240, 2697-2703 (2010).

[52] S.E. Bush, D.E. Pataki, and J.R. Ehleringe, Sources of variation in $\delta^{13} \mathrm{C}$ of fossil fuel emissions in Salt Lake City, USA, Appl. Geoch. 22, 715-723 (2007).

[53] P.P. Tans, ${ }^{13} \mathrm{C} /{ }^{12} \mathrm{C}$ of industrial $\mathrm{CO}_{2}$, in: Carbon Cycle Modeling, ed. B. Bolin (John Wiley \& Sons, Chichester, New York, 1981) pp. 127-129.

[54] R.J. Andres, G. Marland, T. Boden, and S. Bischof, Carbon dioxide emissions from fossil fuel consumption and cement manufacture, 1751-1991, and an estimate of their isotopic composition and latitudinal distribution, in: The Carbon Cycle, eds. T.M.L. Wigley, D.S. Schimel (Cambridge University Press, Cambridge, 2000) pp. 53-62.

[55]D. Lopez-Veneroni, The stable carbon isotope composition of PM2.5 and PM10 in Mexico City Metropolitan Area air, Atmos. Environ. 43, 44914502 (2009).

[56] D. Widory, Combustibles, fuels and their combustion products: A view through carbon isotopes, Combust. Theor. Model. 10, 831-841 (2006).

[57] M. Gorka, P.E. Sauer, D. Lewicka-Szczebak, and M.O. Jedrysek, Carbon isotope signature of dissolved inorganic carbon (DIC) in precipitation and atmospheric $\mathrm{CO}_{2}$, Environ. Pollut. 159, 294301 (2011).

[58] B. Mycke, K. Hall, and P. Leplat, Carbon isotopic composition of individual hydrocarbons and associated gases evolved from micro-scale sealed vessel (MSSV) pyrolysis of high molecular weight organic material, Org. Geochem. 21, 787-800 (1994). vertès naftos produktuose (dyzeline, benzine), naudojamuose Lietuvoje, Rytų bei Vakarų Europoje ir kitose pasaulio šalyse. Šios vertès leido identifikuoti naftos gavybos vietą. Nustatyta, kad Lietuvoje ir Rytų Europos šalyse naudojamas dyzelinas ir benzinas yra Rusijoje išgaunamos naftos produktai. Daroma išvada, kad izotopų santykio metodas gali būti taikomas siekiant nustatyti aerozolio dalelių šaltinius (pvz., dyzelino ir benzino degimo produktus), bet būtina atsižvelgti ì pradini naftos produktų izotopų santykį, kuris kinta priklausomai nuo naftos išgavimo vietovès. 